\title{
The Effectiveness of the Question as a Means of Parliamentary Oversight over the Governmental works in the Jordanian Constitutional System
}

\author{
Dr Khaled Khalaf Al-Drou \\ Assistant Professor of Public Law, Faculty of Law - Jadara University-Jordan
}

\begin{abstract}
Parliamentary Questions are an important means of parliamentary control over the work of the government in the parliamentary system. The member of parliament $(M P)$ used the questions to ensure the government is accountable to the parliament for its policies and actions or to ask a minister regarding an issue within the jurisdiction of his ministry or draw the attention of the government on the one hand, and public opinion on the other hand to the existence of errors or deviations in performance Government.

Parliamentary Questions are an important means of parliamentary control over the work of the government in the parliamentary system. The member of parliament $(M P)$ used the questions to ensure the government is accountable to the parliament for its policies and actions or to ask a minister regarding an issue within the jurisdiction of his ministry or draw the attention of the government on the one hand, and public opinion on the other hand to the existence of errors or deviations in performance Government.
\end{abstract}

Keywords: parliamentary system, parliamentary oversight, balance and cooperation between authorities, government, parliament.

DOI: $10.7176 / \mathrm{JLPG} / 90-13$

Publication date:October $31^{\text {st }} 2019$

\section{Introduction:}

In the era of massive scientific development, concepts and lifestyles have changed, Where the duties of States at all levels $\left({ }^{1}\right)$, whether political, security, economic and other risks, increased as a result of this development ,states strive to face these challenges and use the latest methods and techniques that are in line with reality and activate cooperation at all levels.

This will not be done unless in the presence of a strong parliamentary system in that based on cooperation, balance and mutual control between the legislative and executive branches.

The parliamentary system is based on cooperation, balance and mutual control between the legislative and executive branches, each of which has a number of means through which it exercises its control over the actions of the other authority, and the means exercised by the legislative authority in this regard is the parliamentary question where the constitutions of parliamentary states that the legislature has the right to ask questions to members of the executive authority. Laws and legislation of parliaments regulate how this right is exercised.

The Jordanian Constitution of 1952 and its amendments in Article (96) of the Constitution that: "Every member of the Senate and the House of Representatives may address questions and interpellations to the Ministers concerning any of the public matters, in accordance with what is provided for in the by-laws of the House to which that member belongs..."

Article (125) of Rules and Procedures of the Jordanian Council of Representatives' of 2013 and Article (89) of the Jordanian Senate's 2014 Rules of Procedure define the parliamentary question as: "is whether the member inquiries from the prime minister or the ministers about something he does not know about any of the matters that fall within their competence or his desire to verify the occurrence of an incident that has reached his knowledge or inquiring about the government's intention in any matter".Despite the importance of the parliamentary question as a means of parliamentary control over the actions of the government, it aims to clarify a lot of things and actions, and to draw the attention of the government to the existence of some irregularities to remedy. The question is also one of the mechanisms of communication between the parliament and the government, which through it the parliament can identify a lot of public issues which gives the question great importance and effectiveness in influencing the work of government ${ }^{(2)}$.

\footnotetext{
${ }^{1} \mathrm{AL}$ azzam, F ,A,.F. (2019) the adequacy of the international cooperation in means for combating cybercrime and ways to modernize it , research published in the JANUS.NET Journal vol 10 no 1,may , 2019, p 1

${ }^{2}$ Fawzi, S.(1994) Parliament, (analytical comparative study of the parliaments of the world), the first edition, Dar Arab
} 
The importance of the question lies in alerting public opinion to the shortcomings and mistakes of the government performance. On the other hand, some doubt the effectiveness of this method of parliamentary control, as it does not raise the political responsibility of the government and overthrow it.

In this research, the researcher will try to shed light on the effectiveness of this method of parliamentary oversight by examining what is the parliamentary question in the first section, and the conditions and procedures of the parliamentary question in the second section.

\section{The importance of the research}

The importance of this research is that it demonstrates the importance of the parliamentary question in exposing the mistakes and deviations of the members of the government to the public opinion, as well as the effectiveness of this means in overseeing the work of the government, especially since the member of parliament has the right to turn the question into interpellations, and then rises political responsibility to the government.

\section{The objective of the research}

This research aims to examine the nature of the parliamentary question as a means of parliamentary control over the work of the government. The members of the legislature resort to using it in order to elucidate the policy of the government towards a public issue and examine the procedures for the exercise of this method, and its effectiveness by clarifying the outcome of the parliamentary question.

\section{The research problem}

Despite the importance of the parliamentary question as a means of parliamentary control over the work of the government, there are some who question the effectiveness of this control, especially since it does not directly raise the political responsibility of the government and accountability.

\section{Research Methodology:}

The researcher used the analytical approach, by studying the text specified in the Jordanian Constitution of 1952 and the texts stated in the rules of the Jordanian House of Representatives and the regulations of the Jordanian Senate concerning the right of the parliamentary question and the fate to which it belongs.

\section{Chapter One: What is parliamentary question?}

The parliamentary question arose as a means of parliamentary oversight for the first time in England, the cradle of the parliamentary system, it began to be used on November 9, 1721, in the House of Lords, when Earl Cowper asked the Prime Minister a question. It was also used in the House of Commons in 1783, and after sixty years the questions became a complete system and considered a parliamentary procedure ${ }^{(1)}$.

The parliamentary question has been used to the countries that adopted the parliamentary system, including Jordan. The provisions of the Jordanian Constitution of 1952 and its amendments stipulated in Article (96) thereof, on the right of each member of the Senate and the House of Representatives to ask the ministers questions about any public matter, in accord to the rules of procedure of the Council.

The Rules of Procedure of the Jordanian House of Representatives for the year 2013 in chapter twelve of it in articles (125) to (132) clarify the provisions relating to the parliamentary question, and the same if for the bylaws of the Jordanian Senate in Chapter IX of Articles 89 to 93.

The researcher will try to clarify what the parliamentary question is by studying its concept in the first requirement, and its types in the second.

\section{Section One:The concept of parliamentary question}

The Jordanian Constitution of 1952 and its amendments did not include a clear definition of the parliamentary question. However, Article (125) of the Bylaws of the Jordanian House of Representatives of 2013 and Article (89) of the Bylaws of the Jordanian Senate of 2014,defined the parliamentary question as: "the MP inquiries from the prime minister or the ministers about something he does not know about any of the matters that fall within their competence or his desire to verify the occurrence of an incident that has reached his knowledge or inquiring about the government's intention in any matter."

Renaissance, Cairo.p.41

${ }^{1}$ Salam, E, Z.(1983) political control of the work of the executive power in the parliamentary system, the first edition, the world of books, Cairo.pp 25-27. 
One of the jurists also defined the parliamentary question as: "requests for clarifications to a minister to inquiring about something related to the work of his ministry, or to bring the matter to the attention of the government or to irregularities on a subject'(1).

Another jurist defined it as: "enabling members of parliament to inquire about matters they do not know or to bring the matter to the attention of the Government"(2).

Another jurist defined parliamentary questions as: "Clarification or inquiry by a MP or a Senator to the Prime Minister or the Minister for information on a specific matter within his competence relating to his ministry, which is a bilateral relationship between a member of parliament and the minister in which no other member of parliament intervenes. ${ }^{(3)}$ Parliament may waive it or refer it to interpellations if he is not satisfied with the answer of the Minister. The question is a form of parliamentary control exercised by any member of the Senate or the House of Representatives without impeding political responsibility. The researcher believes that the latter definition is a comprehensive definition of the parliamentary question because it clarifies its nature that it is just a clarification or inquiry, and it indicates the person who is entitled to exercise this right ,a MP or a Senator. It also explains who is asked the question the prime minister or the minister.

The last definition mentions the purpose of the parliamentary question, which is to clarify an issue that falls within the competence of the minister or his ministry.

It also clarifies what distinguishes the parliamentary question from other means of parliamentary oversight as it is a personal right of a member of Parliament, and he maintains a bilateral relationship between him and the Minister without any interferences from any other member.

It indicates the result of the parliamentary question that is the possibility of turning it into an interrogation, and without raising any political responsibility of the government, but the researcher believes that this definition lacks the addition of the phrase (it is a constitutional right for each member ...).

\section{Section Two :Types of Parliamentary Questions}

Parliamentary questions are divided into two main types: oral and written questions, and the researcher will try to study each type separately, through the following:

1. Oral Questions (starred question)

2. Oral questions were used earlier than written questions, and they are considered to be the origin of parliamentary questions $^{(4)}$ (Lheidan.2017,p.71) .Therefore, some consider that oral questions are far from being more significant than written questions, since they lead to an open dialogue between Parliament and the Government $^{(5)}$ (Lheidan.2017,p.94) and it requires the presence of the required Minister before the Parliament to answer questions addressed to him, contrary to written questions that do not require the presence of the minister, as the answer is usually sufficient for the member ${ }^{(6)}$.

Oral questions raise many important issues, but it should be noted that this type of question was not decided to allow the MP to express his opinion, but rather a method whereby a member of Parliament could orally question the competent member of the executive branch $^{(7)}$.

Oral questions are usually characterized by a short response time, because of the importance of the question in which the questioner urgently wait for the response, such questions are raised in matters of a general nature of discussion in the Council, for example, questions arising when discussing the budget, when a subject of the utmost importance , a concern for the public interest is not likely to be delayed, or related to emergency circumstances that are of interest to national public opinion requiring urgent attention by the Government through Parliament ${ }^{(8)}$

\footnotetext{
${ }^{1}$ Sha'ar, R,T,(2005) The General Theory of Constitutional Law, Fifth Edition, Dar Al-Nahda Al-Arabiya, Cairo.p.509

2 Tamawi, S, M.(1996) the three authorities in the contemporary Arab constitutions and in Islamic political thought (composition, terms of reference and relationship between them), the sixth edition, Dar Arab thought, Cairo.

${ }^{3}$ Khatib, N, A.(2017) The Simple in the Constitutional System, Second Edition, Dar Al-Thaqafa, Amman.p.306

${ }^{4}$ Luhaidan, A, H.(2007) means of parliamentary control over the work of the executive authority (a comparative study), Master Thesis, Faculty of Political Science, King Abdulaziz University.p.71

${ }^{5}$ Luhaidan, op,cit p94

${ }^{6}$ Tarbush, Q,M.(1995) Legislative Power in Arab Republican Countries (Comparative Legal Analysis), First Edition, University Foundation for Studies, Publishing and Distribution, Beirut.p371.

${ }^{7}$ Fawzi,op,cit p 110 .

8 Kanan, N.(2009) The Parliamentary Question, (An Applied Comparative Study on the Federal National Council), University of Sharjah Journal for Forensic and Human Sciences, Volume (6), Issue (1) p255.
} 
Article (130) of the Bylaws of the Jordanian House of Representatives,

Article (92) of the bylaws of the Jordanian Senate for the year 2014 stated that the conditions for questions do not apply to questions addressed to ministers during the consideration of the general budget, the budgets of government units and draft laws.

Oral questions are divided into different types, including oral questions without discussion, oral questions with discussion, examination questions, oral questions with the approval of the Minister, and urgent questions ${ }^{(1)}$

Each type of question in comparative parliamentary systems, such as the French political system, the English political system, and others, has special characteristics

2.Written Questions.(Unstarred Questions)

Paragraph (a) of Article (126) of the Bylaws of the House of Representatives of Jordan, 2013, stipulates that the question " The member shall submit the question in writing to the Chairperson..", which is also provided for in the paragraph (a) of Article (90) of the Rules of Procedure of the Jordanian Senate of 2013.

A written parliamentary question is one that is asked by a MP in writing form, and the Government's respond to it shall be also in writing, for clarification on a matter of public interest ${ }^{(2)}$

This type of question was used as a means of obtaining the data and information needed by MP, which requires time to prepare which could not be obtained through the use of oral questions, especially if the questions concerned statistical and financial matters ${ }^{(3)}$ written questions were also used to obtain explanations of texts, laws and regulations ${ }^{(4)}$.

Written questions are the result of the development and research on the different effective means to strengthen parliamentary work. These questions and written replies benefit from the wide publicity and indicate the interest of deputies in the concerns of voters, and obliges the executive authority to take a position, which is published in the official newspaper. Originally, all types of parliamentary questions, including verbal ones, are written to members of the government, and end once the MP gets the minister's answer ${ }^{(5)}$.

The researcher believes that written questions are more effective means than oral questions as a means of parliamentary control over the work of the government, because written questions and the government replies can be published in the media, and thus inform the public opinion to assess the performance of the government, its shortcomings that may occur while exercising its powers. Thus, after we got to know what the parliamentary question is by defining the parliamentary question and studying its types, we will examine the conditions and procedures of the parliamentary question and its consequent in the second section of this research.

Chapter Two: Conditions and procedures of the parliamentary question and its consequent

The Rules of Procedures of parliaments determine the conditions that must be met in the parliamentary question and to be considered acceptable and be tabulated in the sessions of the House of Representatives. It also specifies the procedures to be followed in addressing and replying the parliamentary question, as well as clarifying the consequent actions of the parliamentary question. The researcher will try to clarify the conditions and procedures. In the first section, the outcomes of the question in the second section.

\section{Section One:Conditions and Procedures of Parliamentary question}

There are several formal and content conditions that must be met to accept the parliamentary question, and there are several procedures to be followed in submitting and replying the parliamentary question, which will be addressed by the researcher through the following:

First. Conditions of the parliamentary question:

The bylaws of parliaments require form and content conditions in the parliamentary question, as follows:

A. Formal Questions

\footnotetext{
${ }^{1}$ Tabtabai, A, T.(1987) parliamentary questions, its origins, types, functions, first edition, without mentioning the publisher, Kuwait.p145.

${ }^{2}$ Fawziop,cit,p107

${ }^{3}$ Yousef, M, A.(1998) means of parliamentary control over the work of the government in the parliamentary system, the first edition, Dar Arab Renaissance, Cairo.p114.

${ }^{4}$ Tarbush,op,cit .p.372

${ }^{5}$ Abdel Sadeq, S.(1982) The Origins of Parliamentary Practice, First Edition, Egyptian General Book Organization, Cairo.p.377.
} 
1. Writing the question: This condition stipulated in paragraph (a) of Article (126) of the Bylaws of the Jordanian House of Representatives of 2013, as well as paragraph (a) of the Bylaws of the Jordanian Senate of 2014, and the purpose of this condition is to allow time and room for the minister in charge to enable him to prepare the reply to the question, research and gather the required data so as not to surprise the minister in charge ${ }^{(1)}$.

2. Clarity and abbreviation of the question: This condition stipulated in paragraph (b) of Article (126) of the bylaws of the Jordanian House of Representatives 0f 2013, as well as paragraph (b) of Article (90) of the Jordanian Senate Law of 2014." The question should be brief, focused on the facts."(2)

3. The question is addressed to the competent minister: because the question is related to the function of the minister in charge, so it is not permissible to ask the question to minister who are not specialized in the subject matter.

This condition stipulates that the question shall not have an impact over the interests of the state or the administration of the government, especially since the question does not arouse controversy between the member of the Parliament and the minister in charge, and does not raise a public debate on topics where other members interfere. The question may not be signed by more than one member and may only be addressed to one minister: This provision is stipulated in Article (127) of the Bylaws of the Jordanian House of Representatives and paragraph (a) of Article (90) of the Bylaws of the Jordanian Senate.

4. The question is free from comment

\section{B:Content conditions}

1- The question is free of inappropriate terms: This clause stipulated in paragraph (c) of Article (126) of the Jordanian Bylaws of 2013, as stated in paragraph (b) of Article (90) of the Bylaws of the Jordanian Senate of the year 2013. 2014, avoiding the words and phrases that contains offensive or inappropriate language describing the person responsible minister, or work of his ministry, the question thus turns from a questioning and censorship tool to a means of attack and personal criticism.

2- The question does not violate the provisions of the Constitution or does not harm the public interest, such as leading to the disclosure of some information of a confidential nature or asking the question to provoke a dispute or disagreement with another State. This condition was mentioned in paragraph (c) of Article (90) of the Bylaws of the Jordanian Senate, and paragraph (c) of Article (126) of the Bylaws of the House of Representatives of Jordan, which ignored mentioning the condition that the question does not harm the public interest.

3- The question is related to a matter of general importance and is not related to the person or member of Parliament. This provision is stipulated in paragraph (e) of Article (126) of the Bylaws of the Jordanian House of Representatives and paragraph (f) of Article (90) of the Bylaws of the Jordanian Senate.

4- The question may not be prejudicial to an order of the courts: Paragraph (d) of Article (126) of the Bylaws of the House of Representatives of Jordan in 2013, as well as paragraph (e) of Article (90) of the Bylaws of the Jordanian Senate of 2014, which then added that the question may not indicates what is published in the media.

Second : The procedures of the parliamentary question

If the conditions for the validity of the question are satisfied, the question shall be considered, and the Council shall take several procedures, including informing the Minister to whom the question is being addressed.

This procedure is agreed upon by the Parliamentary Regulations as a prerequisite for the right to question, whether written or oral. ${ }^{(3)}$

\footnotetext{
${ }^{1}$ Kanan,op,cit,p.254

${ }^{2}$ Tabatabai,op,cit,p52

${ }^{3}$ Mustafa, H.(2006) Mutual Control between the Legislative and Executive Authorities, First Edition, Dar Al-Nahda AlArabiya, Cairo, 2006.p.103.
} 
However, if the necessary conditions for the validity of the question are not met, it shall not be considered valid and shall not be included in the agenda for reply ${ }^{(1)}$

Article (128) of the Bylaws of the Jordanian House of Representatives of 2013 clarifies the procedures of the parliamentary question, as The Chairman shall notify the competent minister within seven days from the date of its submission. The Minister shall reply to the question in writing within a period not exceeding fourteen days. The Chairman shall notify the MP who submitted the question within fourteen days from the date of receipt. The question and reply shall be tabled on the agenda of the first session devoted to questions, interrogations and suggestions. If the answer is not satisfied, the question and answer shall be written in the agenda, as stated in Article (129) of the same regulation. When the question and answer are put on the agenda, the MP shall be given the right to speak and the minister shall be given the right of reply If the MP suffices to reply, the discussion of the matter will be closed.

Otherwise, the MP has the right to speak again or to convert the question into interpellation in accordance with the provisions of these rules of procedure of the House of Representatives. No member shall be allowed to speak on the question unless it affects his person as he is entitled to comment briefly.

However, Article (130) of the Bylaws of the Jordanian House of Representatives excludes the questions that are addressed to the ministers during the consideration of the general budget and the budgets of the government units and the draft laws from the conditions of the questions. It authorized each member to intervene in each question and respond to it. Article(131) of the Bylaws of the Jordanian House of Representatives stipulates that questions submitted at a previous session are not included in the agenda of the next session unless MPs declare their adherence to a written letter to the President of the Council, questions are also not put back on the agenda if the Mp who asked the question is absent from the session on which they were listed without excuse.

The bylaws of the Jordanian Senate included procedures like those provided for in the bylaws of the House of Representatives, they do not differ from them except in certain periods. Article (91) of the Bylaws of the Jordanian Senate stipulates that the President of the Senate shall report the question to the competent minister if its conditions are met. However, this law did not specify a period for this, contrary to what the rules of procedures of the Jordanian parliament did. The Minister shall answer the question within a maximum period of eight days, which is a shorter period than that stipulated in the bylaws of the Jordanian House of Representatives.

The Chairman shall communicate the answer to the Mp who asked the question, and the question and answer shall be placed on the agenda of the Council.

The bylaws of the Jordanian Senate did not include a text concerning the questions submitted at a previous session, or if the Mp who ask the question would be absent from the session, which was included without any excuse.

\section{Section Two :The consequential actions of the parliamentary question}

The effectiveness of the parliamentary question as a means of parliamentary oversight on the work of the executive branch, is determined by the consequential actions.

Therefore, the effectiveness of the parliamentary question was a controversial issue among some jurists who were divided into two groups, The first group believes that the question is not a means of parliamentary control over government actions, and that questions are just intended to exchange views between the legislative and executive authorities, and this is what Dr. Yahya al-Jamal support when he stated: "The question is a form of cooperation and exchange of information, not a form of oversight ${ }^{(2)}$

While another group of jurists, including Dr. Fathi Abdul Nabi Weheidi, argued that the question is one of the means of parliamentary oversight of government actions, this is clearly demonstrated by the possibility of turning the parliamentary question into a parliamentary interpellation, and this makes the parliamentary question have a characteristic of oversight and does not keep it merely a manifestation of cooperation and exchange of views between the Government and Parliament ${ }^{(3)}$.

\footnotetext{
${ }^{1}$ Abdel Salam, A.(2006)The Evolution of Constitutional Systems, (Comparative Study), Book II, Part I, Constitutional Development in Egypt from 1837 to 1971, First Edition, Dar Al-Nahda Al-Arabiya, Cairo.,p198

${ }^{2}$ Wahidi, F, A.(1982) Guarantees of the Effectiveness of Constitutional Rules, (Ph.D.), Cairo University.p90.

${ }^{3}$ Wahidi,op,cit p.90
} 
The researcher supports the direction which support the opinion that the parliamentary question is one of the means of parliamentary controls. This will be discussed by examining the outcome of the parliamentary question, through the following:

1: The consequential actions of the Parliamentary Question if it is answered:

After the Minister has answered the question, by providing a set of statements which may convince the Mp who inquiries about the proper conduct of the government or the fact of the matter inquiring about it, the parliamentary question ends, The member of Parliament may not be convinced by the given answer, so he seeks to use one of the means of parliamentary control to collect sufficient evidence, including a new question to be answered orally or seeking to turn the question into interpellation ${ }^{(1)}$.

Thus, the consequent actions of the parliamentary question, if answered, it only takes one direction:

I. The first direction: The MP who asked the question is convinced by the answer.

II. The second direction: The MP who asked the question is not convinced by the answer.

First: The MP who asked the question is convinced by the answer. If the Minister responds verbally to the parliamentary question at the meeting, the MP who asked the question should, if he is convinced, declare that he is convinced of the answer explicitly. This means that the MP or the Senator has achieved the desired purpose of asking the question and is satisfied with the actions the government intends to take towards the incident it was inquiring about, in which case the question is completely over. ${ }^{(2)}$

\section{Second: The MP who asked the question is not convinced by the answer.}

If the MP who asked the question is not satisfied with the answer given by the Minister or the Prime Minister because of the insufficient response to all the aspects raised in the question, in this case the MP has the right to request a reasonable answer to his question ${ }^{(3)}$, if he does not receive such an answer ${ }^{(4)}$,He has the right to turn the question into an interpellation. As rules and procedures of parliaments have permitted the question of parliamentary to be turned into interpellation when the accountable minister refuses to answer it, or when the answer is insufficient, uncertain or credible.

(Article (129) (a) of the Rules of Procedure of the Jordanian House of Representatives and Article 91 (a) of the Rules of Procedure of the Jordanian Senate). ${ }^{(5)}$

If the answer confirms the conviction of the responsible minister individually or the government combined, or when the government refuses to answer the parliamentary question within the time period specified by the rules of procedure of the council as of the receipt of the question, that is stipulated in paragraph (b) of Article (132) of the Bylaws of the Jordanian House of Representatives for 2013, paragraph (b) of Article (93) of the Bylaws of the Jordanian Senate of 2014, which stated: "The question may be referred to a interpellation, but not at the session at which the question is discussed, and the question may be referred to interpellation if the government does not answer within one month of the question being received.

The reason for this is the fear that the one who asked the question may have been forced to make this request under the weight of emotion, the severity of the anger resulting from the refusal of the minister to answer, provide incomplete information, or provide an answer with ambiguity and uncertainty, which leads the questioner to doubt that the minister makes fun of him.

This condition is intended to create an appropriate psychological atmosphere that gives the him the opportunity to think about it carefully and calmly and then comes out with a balanced and wise decision, making sure that his desire for this request comes from the same stable calm and not disturbed and tense ${ }^{(6)}$,paragraph (a) of Article (132) of the rules of procedure of the House of Representatives of Jordan of 2013 and paragraph (a) of the rules of procedure of the Senate of 2014 stated on the need to give the opportunity to provide the conditions and procedures for interpellation.

\footnotetext{
${ }^{1}$ Al-Hiti, Noaman Atallah, Censorship of the Government, First Edition, Dar Raslan, Damascus, 2007, p. 133.

${ }^{2}$ Rabie, Amr Hashem, Parliamentary Oversight in Political Systems, Ibid., P. 518.

${ }^{3}$ Yousef, op,cit p. 203.

${ }^{4}$ Hasbo, Amr Ahmed, Parliamentary Committees, (Comparative Study), First Edition, without mentioning a publisher, or place of publication, 1994, p. 43.

${ }_{5}^{5}$ Abu Younis, Mohamed Bahi, Parliamentary Oversight of Government Work, 2nd Edition, New University House, Alexandria, 2017, p. 81.

${ }^{6}$ Tabatabai, op,cit p. 140.
} 
Two: The outcomes of the Parliamentary Question if it is not answered:

Originally, it is necessary to answer parliamentary questions, but there are some cases where the question can end unanswered, including:

I. The contradiction of Answer with the Public Interest:

Assuming that the question is not prejudicial to the public interest or contrary to the provisions of the Constitution as mentioned earlier, the question is opposing to the public interest and harms it when the answer to it leads to the disclosure of secrets that are prohibited by law, such as military secrets ${ }^{(1)}$.

Second: Refrain from answering for lack of competence: The Minister may refuse to answer some questions on the grounds that the subject of the question does not fall within the tasks entrusted to $\operatorname{him}^{(2)}$.

III. Apologies for answering questions because they are difficult and sometimes impossible:

That is, the information or data required by the Minister is enormous that it cannot be collected easily, or that it is impossible to provide the information requested by the Member of Parliament so that it is difficult for the Minister to answer the question ${ }^{(3)}$.

Fourth: Dropping the question due to the demise of membership of the MP.

Fifth - Dropping the question because of the demise of the official: The status of a member of the executive authority to which the question was asked for his resignation, or dismissal, or the resignation of the government of which he is a member ${ }^{(4)}$.

Sixth: Dropping the question due to the end of the legislative term or the session during which the question was submitted: According to parliamentary traditions, the question is dropped when the legislative role ends. The bylaws and bylaws of some parliaments stipulate that questions will be terminated at the end of the session, as is the case in the Jordanian by-laws of 2013, where paragraph (a) of Article (131) stipulates that: "Questions submitted at a previous session shall not be included in the agenda of the following session unless the MPs have stated that they will adhere to them in writing to the President of the Council."

Seventh : Waiver of the question: The waiver of the question is a constitutional right that reflects the personal aspect of it, this waiver takes one of two forms, either explicit waiver, or implicit waiver ${ }^{(5)}$.

\section{Conclusion:}

At the end of our study on the effectiveness of the question as a means of parliamentary control over the work of government, what it is, its types ,the conditions that must be met in the parliamentary question, the procedures to be followed in the inclusion of the question in the parliament's agenda, in the answer to the parliamentary question, and the outcome of the parliamentary question. We have concluded that the parliamentary question is one of the means of effective parliamentary oversight, where the parliamentary question can be turned into interpellation in order to raise the political responsibility of the government and overthrow, and in the light of what has been studied and the researcher concluded and recommended the following:

\section{Results:}

1. Parliamentary question is one of the means of parliamentary control over the work of the government in the parliamentary system, and its purpose is to inquire about matters unknown to the MP or the Senator, or to draw the attention of the government to a particular topic.

2. The parliamentary question is an individual means of parliamentary oversight. The Jordanian Constitution, the bylaws of the House of Representatives, and the bylaws of the Senate provide for the right of each member of the House to ask questions to ministers.

3. The parliamentary question establishes a bilateral relationship between the MP, the Senator and the charge minister, in which no other MP or Senator intervenes.

4. Since a parliamentary question is a personal right of a member of Parliament, he may waive it or refer it to interpellation if he is not satisfied with the Minister's answer.

\footnotetext{
${ }^{1}$ Tabatabai, op,cit P. 115.

${ }^{2}$ Kanan, op,cit. P. 274.

${ }^{3}$ Othman, A, A.(2009) Parliamentary Questions in Kuwait, (Master), Faculty of Law, Kuwait University, nd, p. 35.

${ }^{4}$ Tabatabai, op. Cit., P. 125.

${ }^{5}$ Yousef op.cit., P. 193.
} 
5. The parliamentary question derives its effectiveness from the outcomes it ends with, namely the possibility of turning it into an interrogation in preparation for raising the political responsibility of the ministry in case it is discovered that it has occurred in errors or deviations.

6. There are situations where the parliamentary question can end unanswered, as in the case of a conflict of interest with the public interest and others.

\section{Recommendations :}

Calls upon the Jordanian legislator to

1. Specify a period in the bylaws of the Jordanian Senate, during which the question must be submitted to the responsible minister, as stated in the bylaws of the Jordanian House of Representatives.

2. Reduce the period stipulated in the bylaws of the Jordanian House of Representatives, during which the Minister must answer the question from fourteen days to a week, which is sufficient time to answer, in order to prevent procrastination and wasting interest from asking the question.

3. Establish special rules for urgent questions in the bylaws of the House of Representatives and the Senate, and to set short periods to answer them, because there are questions that cannot delay.

4. Explicitly provide for cases in which a member of the executive authority may exclusively refrain from answering questions, so as not to use the term public interest as an excuse to evade parliamentary questions.

\section{References}

-Abdel Sadeq, S.(1982) The Origins of Parliamentary Practice, First Edition, Egyptian General Book Organization, Cairo.

-Abdel Salam, A.(2006)The Evolution of Constitutional Systems, (Comparative Study), Book II, Part I, Constitutional Development in Egypt from 1837 to 1971, First Edition, Dar Al-Nahda Al-Arabiya, Cairo.

-Abu Younis, M, B.(2017) Parliamentary Oversight of Government Work, 2nd edition, New University House, Alexandria.

-ALazzam, F,A,F.(2019) the adequacy of international cooperation means for Combating Cybercrime and waysto modernize it, research published in the Janus.net Journal,vol10nolmay, University of Lisbon,Portugal, 2019, p 1

-Fawzi, S.(1994) Parliament, (analytical comparative study of the parliaments of the world), the first edition, Dar Arab Renaissance, Cairo.

-Hassabo, A,A.(1994) parliamentary committees, (a comparative study), the first edition, without mentioning a publisher, or place of publication.

-Kanan, N.(2009) The Parliamentary Question, (An Applied Comparative Study on the Federal National Council), University of Sharjah Journal for Forensic and Human Sciences, Volume (6), Issue (1).

-Khatib, N, A.(2017) The Simple in the Constitutional System, Second Edition, Dar Al-Thaqafa, Amman.

-Luhaidan, A, H.(2007) means of parliamentary control over the work of the executive authority (a comparative study), Master Thesis, Faculty of Political Science, King Abdulaziz University.

-Mustafa, H.(2006) Mutual Control between the Legislative and Executive Authorities, First Edition, Dar A1Nahda Al-Arabiya, Cairo, 2006.

-Hiti, N, A.(2007) Censorship of the Government, First Edition, Dar Raslan, Damascus.

-Othman, A.( 2009 ) Parliamentary Questions in Kuwait, (Master), Faculty of Law, Kuwait University.

-Salam, E, Z.(1983) political control of the work of the executive power in the parliamentary system, the first edition, the world of books, Cairo.

-Sha'ar, R,T,(2005) The General Theory of Constitutional Law, Fifth Edition, Dar Al-Nahda Al-Arabiya, Cairo.

-Tabtabai, A, T.(1987) parliamentary questions, its origins, types, functions, first edition, without mentioning the publisher, Kuwait.

-Tamawi, S, M.(1996) the three authorities in the contemporary Arab constitutions and in Islamic political thought (composition, terms of reference and relationship between them), the sixth edition, Dar Arab thought, Cairo.

-Tarbosh, Q,M.(1995) Legislative Power in Arab Republican Countries (Comparative Legal Analysis), First Edition, University Foundation for Studies, Publishing and Distribution, Beirut.

-Wahidi, F, A.(1982) Guarantees of the Effectiveness of Constitutional Rules, (Ph.D.), Cairo University.

- Yousef, M, A.(1998) means of parliamentary control over the work of the government in the parliamentary system, the first edition, Dar Arab Renaissance, Cairo. 